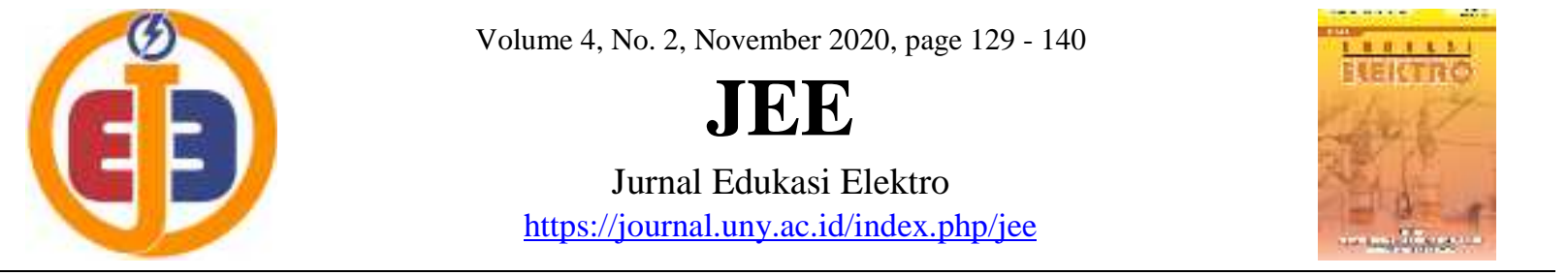

\title{
Peningkatan Hasil Belajar Siswa dengan Metode Internalisasi Karakter Disiplin
}

\author{
Budi Lestari $^{1}$, Iin Endyah Susilowati ${ }^{2}$ \\ ${ }^{1,2}$ Jurusan Teknik Komputer Jaringan, SMK N 2 Pengasih Kulon Progo, Indonesia \\ ${ }^{1}$ lesta.bd@gmail.com* \\ * corresponding author
}

\begin{abstract}
This study aimed to determine whether there was an improvement in the learning outcomes of students who learn Basic Computer Networks subject with the discipline character internalization strategy. The method used in this study was action research that was conducted in two cycles. Each cycle consisted of four stages, namely planning, acting, observing, and reflecting. The students involved in this study were $X$ grade students of the Network Computer Techniques Department of SMK N 2 Pengasih. The data collection was done through two different instruments. The first one was the observation sheet that was used to determine the value of discipline character internalization. The second was a post-test that was used to measure the students' learning outcomes. The result showed that there was an improvement in the students' learning outcomes. It proved by the improvement of students' learning outcomes from 67.51 to 88.11 for the first and second cycle of action research, respectively. The result of observation also showed that there was an improvement in the disciplinary character of students. It was evident from the data acquisition in cycle I in which $65.7 \%$ increasing to $90 \%$ in cycle II.
\end{abstract}

Article Info

\footnotetext{
ABSTRAK

Penelitian ini dilakukan dengan tujuan untuk mengetahui apakah ada peningkatan nilai hasil belajar siswa yang sedang belajar mata pelajaran Komputer Jaringan Dasar dengan menggunakan strategi internalisasi karakter disiplin. Metode yang diterapkan dalam melakukan penelitian ini adalah penelitian tindakan kelas yang dilaksanakan melalui dua siklus. Setiap siklus terdiri dari empat tahapan yaitu perencanaan, tindakan, observasi, dan refleksi. Subyek yang dipilih dalam penelitian ini adalah siswa kelas X (sepuluh) Kompetensi Keahlian Teknik Komputer Jaringan di SMK N 2 Pengasih. Proses dalam melakukan pengumpulan data dengan menggunakan dua instrumen berbeda. Instrumen pertama adalah lembar observasi yang digunakan untuk mengetahui nilai internalisasi karakter disiplin. Instrumen kedua adalah post-test yang digunakan untuk mengukur hasil belajar siswa. Hasil penelitian menunjukkan bahwa ada peningkatan hasil belajar siswa. Hal ini dibuktikan dengan peningkatan hasil belajar siswa berturut-turut dari 67,51 menjadi 88,11 pada siklus I dan II. Hasil observasi juga menunjukkan adanya peningkatan karakter disiplin siswa. Terbukti dari perolehan data pada siklus I sebesar $65,70 \%$ meningkat menjadi $90,00 \%$ pada siklus II.
} 


\section{PENDAHULUAN}

Kualitas manusia yang ingin dihasilkan oleh pendidikan seperti tercantum dalam tujuan pendidikan nasional menurut Undang-Undang RI No. 20 Tahun 2003 tentang Sistem Pendidikan Nasional adalah meningkatkan kualitas manusia, yaitu manusia yang berilmu dan bertakwa terhadap Tuhan Yang Maha Esa, berbudi luhur, berkepribadian, mandiri, maju, tangguh, cerdas, kreatif, terampil, disiplin, bertanggung jawab, dan produktif serta sehat jasmani dan rohani. Jika pendidikan tidak sesuai dengan Tujuan Pendidikan Nasional tersebut maka bangsa ini tidak akan menedapatkan kualitas SDM yang memiliki kesempurnaan akhlak dan rohani. Untuk menciptakan insan yang berkualitas tentu sangat dituntut perannya dalam hal ini adalah pendidikan formal. Salah satu upaya pendidikan formal dalam mencapai keberhasilan tersebut dan mudah dalam pencapaian tujuan yang diharapkan adalah menetapkan peraturanperaturan agar seluruh komponen menjadi disiplin. Dalam hal ini yang dimaksud dengan disiplin adalah mengikuti dan menaati peraturan, nilai, dan hukum yang berlaku (Tulus, 2004:33).

Masykur (2011:64) mengatakan bahwa disiplin berasal dari bahasa Inggris "discipline" yang mengandung beberapa arti. Diantaranya adalah pengendalian diri, membentuk karakter yang bermoral, memperbaiki dengan sangsi, serta kumpulan beberapa tata tertib untuk mengatur tingkah laku. Disiplin juga merupakan upaya untuk membentuk tingkah laku sesuai dengan yang sudah ditetapkan untuk mencapai sesuatu yang lebih baik dan diharapkan. Terkait dengan hal itu, sekolah yang memiliki tata tertib jelas bermaksud untuk mendisiplinkan guru dan murid agar bisa mencapai tingkat tertinggi dalam prestasi belajar-mengajar. (Rahman, 2011:66).

Menurut Moenir (2010:94), disiplin adalah "suatu bentuk ketaatan terhadap aturan, baik tertulis maupun tidak tertulis yang telah ditetapkan”. Selain itu Moenir (2010:95) juga menyatakan bahwa disiplin ada dua jenis, yaitu disiplin waktu dan disiplin perbuatan. Mengenai disiplin ada dua jenis yang sangat dominan dalam usaha menghasilkan barang dan jasa sesuai dengan apa yang dikehendaki organisasi. Kedua disiplin itu adalah disiplin dalam hal waktu dan disiplin dalam hal kerja atau perbuatan. Kedua jenis disiplin tersebut merupakan kesatuan yang tidak dapat dipisahkan serta saling mempengaruhi. Dapat saja seseorang hadir tepat waktunya, tetapi tidak segera melakukan perbuatan sesuai ketentuan organisasi pada hakekatnya merugikan organisasi.

Ahmad (2010) berpendapat bahwa disiplin timbul dari kebutuhan untuk mengadakan keseimbangan antara apa yang ingin dilakukan individu dan apa yang diinginkan individu dari orang lain sampai batas-batas tertentu dan memenuhi tuntutan orang lain dari dirinya sesuai dengan kemampuan yang dimilikinya dan dari perkembangan yang lebih luas. Dengan disiplin, peserta didik bersedia untuk patuh mengikuti peraturan yang telah ditetapkan dan menjauhi larangan tertentu. Kesediaan seperti ini harus dipelajari dan harus secara sadar diterima dalam rangka memelihara kepentingan bersama atau memelihara kelancaran tugas-tugas sekolah. Disiplin dapat ditingkatkan melalui pelatihan, pengawasan dan pembiasaan sehingga tercipta keadaan yang tertib dan patuh pada individu agar terbentuk individu yang dapat disiplin ketika di sekolah.

Dari beberapa pendapat di atas keberhasilan pendidikan dalam suatu sekolah sangat dipengaruhi oleh beberapa faktor, salah satunya adalah kedisiplinan. Kedisiplinan harus ditegakkan oleh semua warga sekolah, salah satunya adalah siswa. Siswa diharapkan untuk selalu disiplin atau tepat waktu dalam mengikuti kegiatan sekolah maupun menyelesaikan tugas pembelajaran. Siswa dalam mengikuti kegiatan pembelajaran tidak akan lepas dari berbagai peraturan dan tata tertib yang berlaku di sekolahnya maupun di bengkel tempat anak-anak melakukan praktek. 
Oleh karena itu, siswa dituntut agar bisa berperilaku sesuai dengan peraturan dan tata tertib yang berlaku di sekolah maupun di bengkel tersebut. Kepatuhan dan ketaatan siswa terhadap berbagai peraturan dan tata tertib yang berlaku di sekolah maupun di bengkel tempat praktek disebut disiplin siswa.

Secara etimologis, internalisasi menunjukkan suatu proses. Dalam kaidah Bahasa Indonesia akhiran-Isasi mempunyai definisi proses. Oleh karena itu, internalisasi dapat didefinisikan sebagai suatu proses menanamkan sesuatu. Menurut Chaplin (2005:256) internalisasi (internalization) diartikan sebagai penggabungan atau penyatuan sikap, standar tingkah laku, pendapat, dan seterusnya di dalam kepribadian. Selanjutnya, Poerwadarminta (2007:439) mengemukakan bahwa internalisasi adalah penghayatan terhadap pemberian ilmu, doktrin atau nilai, sehingga merupakan keyakinan dan kesadaran akan kebenaran doktrin atau nilai yang diwujudkan dalam sikap dan perilaku.

Proses internalisasi yang dikaitkan dengan pembinaan karakter peserta didik memiliki tiga tahap yang mewakili proses terjadinya internalisasi, yaitu: a) Tahap transformasi nilai. Tahap yang dilakukan oleh pendidik dalam menyampaikan nilai-nilai baik maupun kurang baik pada ranah kognitif. Tahap ini terjadi komunikasi verbal antara pendidik dan peserta didik yang bersifat memberikan pengetahuan. b) Tahap transaksi nilai. Tahapan pendidikan dengan melakukan komunikasi dua arah, atau komunikasi antara peserta didik dengan pendidik yang bersifat komunikasi timbal balik. Tahapan ini memberikan pengaruh melalui nilai untuk menentukan nilai sesuai yang telah dijalankan oleh peserta didik tersebut. c) Tahap Transinternalisasi. Tahap ini dilakukan lebih mendalam dengan menggunakan komunikasi verbal beserta sikap mental dan kepribadian. Dalam tahapan ini peserta didik akan memperhatikan dan memiliki kecenderungan meniru sikap dan perilaku yang dilakukan pendidik. Oleh sebab itu, pendidik diharapkan dapat lebih memperhatikan sikap dan perilakunya agar tidak bertentangan dengan pemberian nilai yang diberikan. Adapun tahapan tersebut dihubungkan dengan perkembangan manusia, proses internalisasi dilaksanakan sesuai dengan tugas-tugas perkembangan. Internalisasi yang dihubungkan dengan nilai karakter disiplin diartikan sebagai suatu proses memasukkan nilai-nilai karakter disiplin secara utuh, dan dilanjutkan dengan kesadaran diri mengenai pentingnya sifat disiplin pada diri seseorang sehingga dapat diterapkan pada kehidupan sehari-hari.

Berdasarkan hasil observasi yang dilakukan penulis pada siswa kelas $\mathrm{X}$ TKJ SMK Negeri 2 Pengasih pada mata pelajaran Komputer Jaringan Dasar, masih ditemukan siswa yang masuk kelas terlambat, masih ada siswa yang tidak menggunakan seragam pakaian kerja (wear pack), ramai sendiri pada saat guru menjelaskan materi pelajaran, tidak berani bertanya saat belum faham materi yang disampaikan guru, dalam menggunakan peralatan praktek tidak sesuai SOP, tidak mengembalikan peralatan praktek ke tempat semula, dalam mengerjakan maupun mengumpulkan laporan hasil praktek sering tidak tepat waktu, dan ada beberapa siswa yang bertanya ke siswa lain pada saat ujian.

Berdasarkan permasalahan yang telah diuraikan di atas maka dapat dirumuskan pertanyaan penelitian sebagai berikut: pertama, apakah ada peningkatan nilai hasil belajar setelah siswa mengikuti pembelajaran dengan metode internaliasi pada karakter disiplin pada mata pelajaran Komputer Jaringan Dasar kelas $\mathrm{X}$ SMK N 2 Pengasih? kedua, apakah ada peningkatan proses pembelajaran setelah siswa mengikuti pembelajaran dengan metode internalisasi karakter didiplin siswa pada mata pelajaran Komputer Jaringan Dasar kelas X SMK N 2 Pengasih? Tujuan penelitian tindakan kelas ini adalah pertama, untuk mengetahui peningkatan nilai hasil belajar setelah siswa mengikuti pembelajaran dengan metode internaliasi pada karakter disiplin siswa pada mata pelajaran Komputer Jaringan Dasar kelas $\mathrm{X}$ SMK N 2 Pengasih. Kedua, untuk 
mengetahui peningkatan proses pembelajaran setelah siswa mengikuti pembelajaran dengan metode internalisasi karakter disiplin siswa pada mata pelajaran Komputer Jaringan Dasar kelas X SMK N 2 Pengasih. Adapun manfaat dari penelitian ini, agar dapat digunakan sebagai referensi untuk memperbaiki proses pembelajaran sehingga kualitas hasil pembelajarn dapat meningkat, sebagai salah satu motivasi agar para guru aktif dalam melaksanakan proses kegiatan belajar mengajar, khususnya pada mata pelajaran Komputer Jaringan Dasar. Dan siswa dapat lebih aktif dalam mengikuti proses belajar mengajar, memperoleh pengetahuan dan ketrampilan yang lebih berkualitas, lebih memiliki makna dan mendapatkan hasil yang maksimal dalam memperoleh dan menerima pembelajaran.

\section{METODE}

Pendekatan yang penulis gunakan dalam penelitian ini adalah penelitian tindakan kelas. Penelitian ini dilakukan untuk memberikan solusi pada suatu masalah, diujicobakan dalam situasi yang sebenarnya di lapangan. Dengan memperhatikan kekurangan maupun kelebihan serta melakukan perubahan yang berfungsi sebagai salah satu upaya untuk peningkatan. Upaya perbaikan ini dilakukan dengan melaksanakan tindakan untuk mencari jawaban atas permasalahan yang diangkat dari kegiatan sehari-hari di kelas. Cormack (1991) yang dikutip Moleong (2006: 238) menyatakan bahwa penelitian tindakan adalah cara melakukan penelitian dan berupaya bekerja untuk memecahkan masalah pada saat yang bersamaan.

Penelitian tindakan jika diterapkan di kelas merupakan suatu pendekatan untuk memperbaiki pendidikan melalui perubahan, dengan mendorong para guru memikirkan praktik tersebut dan agar mau mengubahnya. Penelitian tindakan bersifat partisipatif dan kolaboratif, karena penelitian ini selain melibatkan guru di dalamnya juga melibatkan orang lain (rekan-rekan) sebagai kolaborator dan merupakan bagian dari suatu penelitian yang hasilnya dapat dinikmati bersama.

Penelitian ini dilakukan dalam konteks perbaikan proses pembelajaran di kelas, penelitian ini juga disebut Penelitian Tindakan Kelas (Classroom Action Research). Penelitian tindakan ini menggunakan prosedur kerja Kemmis dan McTaggart, yang terdiri dan beberapa siklus. Setiap siklus meliputi perencanaan, tindakan, pengamatan, dan refleksi. Setelah siklus I, siklus II dan seterusnya. Apabila tujuan penelitian telah tercapai maka siklus berikutnya tidak dilaksanakan. Setiap siklus terdiri dari empat tahapan, yaitu Perencanaan (Plan), Tindakan (Act), Observasi (Observe), dan refleksi (Reflect).

Waktu penelitian ini dilaksanakan pada semester genap tahun ajaran 2019/2020, yaitu pada bulan Januari sampai dengan bulan Maret 2020. Pembelajaran dengan metode internalisasi karakter disiplin siswa pada mata pelajaran Komputer Jaringan Dasar di laksanakan pada rentang waktu tersebut.

Penelitian dilakukan di SMK N 2 Pengasih yang beralamat di Jl. Krt. Kertodingrat, Margosari, Pengasih, Kulon Progo. Penelitian dilaksanakan di Bengkel Teknik Komputer Jaringan yang di dalamnya terdapat peralatan yang dapat menunjang praktek untuk mengasah kemampuan psikomotorik (skill) anak.

Subyek penelitian ini adalah sebanyak 35 siswa dan pengampu pelajaran pada kelas $\mathrm{X}$ Teknik Komputer Jaringan SMK N 2 Pengasih, Kulon Progo.

Prosedur penelitian tindakan kelas ini dilaksanakan melalui dua siklus. Tiap siklus dilaksanakan sesuai dengan perubahan yang ingin diraih. Adapun variabel prosedur dari penelitian ini meliputi (1) perencanaan (planning), (2) pelaksanaan tindakan (action), (3) observasi (observation), dan (4) refleksi (reflection) dalam setiap siklus. Kegiatan yang dilakukan dalam tahap perencanaan ini adalah menentukan bahan ajar yang akan disampaikan kepada peserta didik, membuat skenario proses 
pembelajaran dengan menerapkan nilai-nilai disiplin pada proses pembelajaran, menyiapkan lembar observasi yang digunakan sebagai instrumen untuk melihat bagaimana kondisi proses belajar mengajar di kelas ketika rencana pembelajaran tersebut diterapkan, membuat media pembelajaran sebagai alat bantu mengajar yang diperlukan dalam rangka optimalisasi pembelajaran, dan membuat instrumen evaluasi yang digunakan untuk melihat apakah penguasaan materi yang disampaikan pada pelajaran tersebut sudah ada peningkatan dan nilai disiplin siswa telah mengalami perubahan menjadi lebih baik.

Tahap pelaksanaan tindakan (action) yang dilakukan adalah: guru dalam menyampaikan materi ajar sesuai dengan materi yang tertuang dalam silabus mata pelajaran, serta sesuai dengan Rencana Pelaksanaan Pembelajaran (RPP) yang telah dibuat, guru memasukkan nilai-nilai disiplin pada proses pembelajaran di kelas, kolaborator dan guru mengadakan observasi setiap kali proses pembelajaran berlangsung secara bergantian, Guru meminta siswa untuk mengisi angket pada akhir pelajaran pada siklus kedua. Hal ini dilakukan untuk melihat sampai sejauh mana keberhasilan dalam melakukan internalisasi nilai-nilai disiplin yang diterapkan pada proses belajar mengajar, melakukan revisi kegiatan integrasi nilai disiplin, yang meliputi materi, waktu pelaksanaan, maupun lama pelaksanaan. Berdasarkan hasil dari obsevasi dalam melaksanakan pembelajaran untuk siklus ke II dengan tindakan sesuai hasil revisi/refleksi dan siklus I, serta mengadakan evaluasi/tes dan menyebar angket.

Pada tahap observasi (observation), kegiatan yang dilakukan meliputi: guru mengamati sikap siswa dalam menerima materi pelajaran yang di dalamnya terkandung nilainilai disiplin, guru meminta semua siswa untuk mengerjakan lembar evaluasi dan angket sikap siswa terhadap proses pembelajaran dan melakukan penilaian terhadap hasil pekerjaan siswa. Pada tahap refleksi (reflection), hasil yang telah diperoleh dalam tahap observasi dikumpulkan serta dianalisis dalam tahap ini. Dari hasil observasi, guru dapat merefleksikan diri dengan melihat data observasi apakah kegiatan yang telah dilakukan telah dapat mengembangkan nilai-nilai disiplin siswa. Data dari lembar observasi juga dapat dipergunakan sebagai acuan bagi guru untuk dapat mengevaluasi dirinya sendiri. Hasil analisis data yang dilaksanakan dalam tahap ini akan dapat dipergunakan sebagai acuan untuk merencanakan siklus berikutnya.

Instrumen penelitian ini menggunakan angket, catatan lapangan, lembar observasi, dan dokumentas. Indikator keberhasilan penelitian tindakan kelas ini dapat dilihat berdasarkan keberhasilan produk dan keberhasilan proses. Indikator keberhasilan produk dilihat dari peningkatan hasil belajar siswa yakni memperoleh rata-rata nilai minimal 75 dan berkembangnya perilaku disiplin siswa, sedangkan indikator keberhasilan proses dilihat dan proses pembelajaran yang dilakukan.

Validitas data sangat diperlukan untuk mendapatkan data dan informasi yang dapat dipertanggungjawabkan kebenarannya. Menurut Burns (1999:161-162), data penelitian tindakan harus memenuhi lima kriteria, yaitu validitas demokratik, validitas proses, validitas hasil, validitas katalitik, dan validitas dialogis. Dari kelima kriteria tersebut, pada penelitian ini hanya digunakan dua kriteria yaitu validitas demokratik dan validitas dialogis. Validitas demokratik dan validitas dialogis ini dilaksanakan pada perencanaan siklus I dan siklus II. Bentuknya yakni (1) dengan melakukan diskusi dengan kolaborator mengenai pembelajaran Komputer Jaringan Dasar yang akan dilaksanakan seperti materi pelajaran, langkah-Iangkah pembelajarannya, media pembelajaran yang akan digunakan, serta evaluasi pembelajaran.

Analisis data dalam penelitian tindakan kelas ini dari data hasil penelitian akan dilakukan analisis dengan dua cara, yaitu, data yang terkait tentang internalisasi nilai-nilai disiplin dalam pembelajaran mata pelajaran Komputer Jaringan Dasar ditafsirkan secara 
kualitatif dan kuantitatif. Adapun data hasil belajar belajar siswa ditafsirkan secara kuantitatif. Sedangkan data hasil jawaban angket siswa yang menyangkut perilaku disiplin siswa dan proses pembelajaran dilakukan secara kuantitatif deskriptif. Data-data yang diperoleh dari angket tersebut ditabulasikan untuk mencari harga rerata, simpangan baku, modus, median, nilai minimun, dan nilai maksimum dan variabel penilaku disiplin. Dalam mencari harga rerata, simpangan baku, modus, median, nilai minimun, dan nilai maksimum menggunakan bantuan program pengolahan statistik.

Hasil pengukuran dalam penelitian ini dapat diketahui dengan menggunakan rerata harapan sebagai kriteria pembanding yang dibedakan menjadi tiga kategori sebagai berikut.

Dikatakan baik, jika $(\mathrm{Mi}+1 \mathrm{SBi})<\mathrm{x}$. Sedangkan kategori sedang jika, (Mi - $1 \mathrm{SBi})<$ $\mathrm{x}<(\mathrm{Mi}+1 \mathrm{SBi})$. Adapun dikatakan kategori buruk, jika $\mathrm{x}<(\mathrm{Mi}-1 \mathrm{SBi})$. Penentuan jarak 1 SB (Simpangan Baku) untuk masing-masing kategori ini didasarkan pada distribusi normal yang secara teoretik berjarak 6 SB (Sutrisno Hadi, 2003). Besarnya rerata harapan (Mi) dihitung menggunakan rumus $\mathrm{Mi}=1 / 2(\mathrm{Nb}+$ $\mathrm{Na}$ ), dimana $\mathrm{Nb}$ adalah nilai harapan terendah dan $\mathrm{Na}$ adalah nilai harapan tertinggi. Untuk menghitung besarnya Simpangan Baku harapan digunakan rumus $\mathrm{SBi}=1 / 6$ (nilai maksimum nilai minimum). Atas dasar nilai rata-rata dan simpangan baku maka dapat disusun kategori untuk masing-masing indikator, yaitu dengan jalan membandingkan skor rata-rata hasil observasi dengan norma yang telah ditentukan masing-masing indikator.

\section{HASIL DAN PEMBAHASAN}

Pelaksanaan penelitian tindakan kelas ini dilakukan dalam dua siklus, yaitu siklus I terdiri atas empat pertemuan, di akhir pertemuan ada tes sebagai evaluasi dari hasil pembelajaran pada pertemuan ke-1 sampai ke-4. Siklus II terdiri atas empat kali pertemuan, di akhir pertemuan juga ada tes sebagai evaluasi dari hasil pembelajaran pada pertemuan ke-1 sampai ke-4. Alokasi waktu pada setiap pertemuan adalah 5x45 menit. Secara detail, jadwal penelitian dapat dilihat pada tabel 1 berikut.

Tabel 1. Jadwal Penelitian Tindakan Kelas

\begin{tabular}{ccl}
\hline No & $\begin{array}{c}\text { Pertemuan } \\
\text { ke- }\end{array}$ & \multicolumn{1}{c}{ Topik } \\
\hline 1 & 1 & $\begin{array}{l}\text { Konsep Jaringan LAN, } \\
\text { MAN, WAN, Internet dan } \\
\text { Wireless }\end{array}$ \\
2 & 2 & Model OSI Layer \\
3 & 3 & IP Address Versi 4 \\
4 & 4 & Subnetting \\
5 & 5 & Post-test I \\
6 & 1 & Topologi Jaringan \\
7 & 2 & Media Transmisi Data \\
8 & 3 & Protokol Jaringan \\
9 & 4 & $\begin{array}{l}\text { Menyajikan jenis-jenis } \\
\text { perangkat jaringan }\end{array}$ \\
10 & 5 & Post-test II \\
\hline
\end{tabular}

Untuk mengetahui permasalahan pada proses pembelajaran mata pelajaran Komputer Jaringan Dasar, guru peneliti dan kolaborator melakukan identifikasi permasalahan menyangkut sikap disiplin yang dimiliki siswa, hal ini dilakukan sebelum melakukan penelitian. Kegiatan tersebut yakni observasi terhadap sikap disiplin pada diri siswa seharihari dan refleksi diri terhadap proses pembelajaran. Observasi dilakukan oleh guru yang juga bertindak sebagai peneliti bersama dengan seorang kolaborator.

Refleksi diri dilakukan oleh guru dengan merenungkan kekurangan-kekurangan yang ada dalam pembelajaran selama ini. Hasil refleksi diri disampaikan kepada kolaborator untuk dicari solusinya. Dari kegiatan observasi dan refleksi diri diperoleh gambaran bahwa ketaatan beribadah dan sikap disiplin di kalangan siswa masih kurang. Hal ini sangat disadari guru mengingat kedua aspek pendidikan karakter di sekolah selama ini kurang mendapat porsi yang memadai dalam pembelajaran, guru kurang menginternalisasikan nilai-nilai pendidikan karakter dalam proses pembelajaran di kelas. 
Pelaksanaan penelitian tindakan pada siklus I, secara umum melalui empat tahapan, yaitu perencanaan, tindakan, observasi dan refleksi. Pada tahap perencanaan pada siklus I, berdasarkan data yang telah dikumpulkan melalui observasi dan refleksi diri, perlu lakukan cara untuk mencari alternatif solusinya. Setelah berdikusi dengan kolaborator, diperoleh kesepakatan bahwa perlu diterapkan suatu metode pembelajaran yang mampu meningkatkan sikap disiplin pada diri siswa. Metode pembelajaran yang dimaksud adalah penerapan internalisasi sikap disiplin pada proses pembelajaran Komputer Jaringan Dasar.

Kemudian guru menyusun sebuah proses pembelajaran yang memunculkan komponenkomponen ketaatan beribadah dan sikap displin. Ketaatan beribadah dilaksanakan dengan mengajak siswa yang beragama Islam untuk melaksanakan Shalat Dzuhur berjamaah setelah kelas dimulai dan berdoa bagi pemeluk agama lain, berdoa sebelum dan setelah proses pembelajaran. Sikap disiplin ditandai dengan penyampaian peraturan-peraturan dan aturan main selama proses pembelajaran, yang meliputi disiplin belajar, disiplin masuk kelas tepat waktu, disiplin mendengarkan dengan seksama penjelasan guru, tidak pernah keluar sebelum pelajaran selesai, mengembalikan alat praktek ke tempat semula, menggunakan peralatan praktek sesuai SOP, mengikuti pelajaran dari awal sampai selesai, tidak menunda-nunda mengerjakan tugas, membuat laporan sesuai waktu yang ditetapkan guru dan datang ke sekolah tepat waktu. Semua nilainilai tersebut diusahakan dapat muncul pada diri siswa selama proses pembelajaran dan diharapkan dapat menjadi bagian kepribadian pada diri siswa. Media yang digunakan dalam proses pembelajaran antara lain laptop, LCD, pakaian dan perlengkapan kerja, dan alat-alat praktik.

Waktu yang digunakan untuk pelaksanaan tindakan pada siklus I ini adalah empat kali pertemuan. Adapun rencana langkah-langkah tindakan pada siklus I yaitu, pertama adalah proses pembelajaran mata pelajaran Komputer Jaringan Dasar dengan lebih menekankan pada keterampilan proses. Langkah kedua, peneliti selaku pelaksana tindakan menentukan materi pelajaran yang meliputi topik-topik: konsep jaringan LAN, MAN, WAN, Internet dan Wireless, model OSI layer, IP Address versi 4 dan subnetting. Ketiga, peneliti selaku pelaksana tindakan menyiapkan bahan pengajaran yang meliputi topik-topik di atas. Keempat, peneliti selaku pelaksana tindakan melaksanakan pengajaran dengan langkah-langkah: apersepsi, penyajian materi, dan menutup pelajaran.

Pada langkah tindakan dalam siklus I dilaksanakan dalam dua tindakan, yaitu tindakan I-II dan tindakan III-IV. Tindakan I dilaksanakan pada hari Rabu tanggal 08 Januari 2020 dan hari Rabu tanggal 15 Januari 2020 dengan materi Konsep Jaringan LAN, MAN, WAN, Internet dan Wireless dan Model OSI Layer. Adapun skenario pembelajaran yang dirancang meliputi: pertama, guru dan siswa berdoa sebelum kelas dimulai. Kedua guru meminta seorang siswa maju ke depan kelas untuk mengidentifikasi Jaringan LAN, MAN, WAN, Internet dan Wireless dan seorang lagi untuk mengidentifikasi Model OSI Layer. Ketiga, siswa pertama mengidentifikasi Jaringan LAN, MAN, WAN, Internet dan Wireless dan siswa kedua mengidentifikasi Model OSI Layer. Gambar di bawah merupakan salah satu kegiatan pembelajaran yakni salah satu bentuk apersepsi, yang menunjukkan siswa berani maju ke depan kelas untuk menjawab pertanyaan yang diberikan guru.

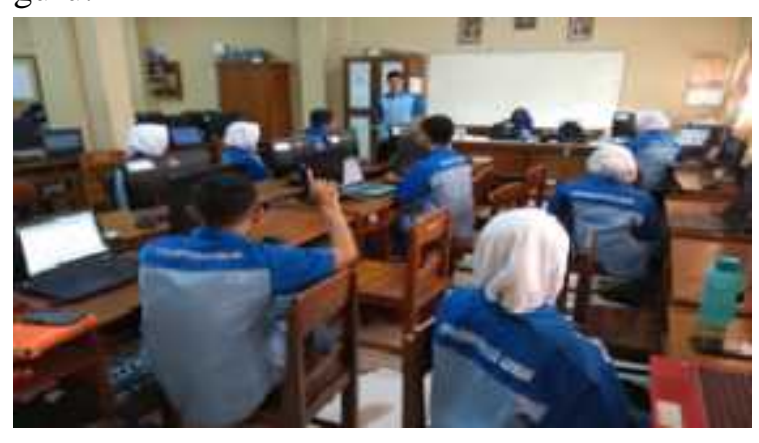

Gambar 1. Suasana pembelajaran (apersepsi) Komputer Jaringan Dasar 
Keempat, kelas dibagi menjadi enam kelompok, tiap-tiap kelompok beranggotakan 6 siswa. Kelima, tiap-tiap kelompok mendiskusikan tentang konsep jenis jaringan Jaringan LAN, MAN, WAN, Internet dan Wireless serta Model OSI Layer, hasil diskusi kemudian dipresentasikan dengan LCD di depan kelas oleh salah satu wakil kelompok dan kelompok yang lain memberikan tanggapan, bertanya atau menyanggah. Keenam, siswa menyimpulkan materi yang dipelajari. Ketujuh, guru memberikan penilaian selama proses pembelajaran berlangsung dan hasil pekerjaan siswa. Kedelapan, guru membantu siswa menyimpulkan dan memberi penguatan atas simpulan yang dibuat siswa dan materi yang dipelajari. Kesembilan, guru melakukan refleksi mengenai pembelajaran yang telah berlangsung dan terakhir guru mengakhiri kegiatan dengan melaksanakan Shalat Dzuhur berjamaah setelah kelas selesai, dan berdoa bagi pemeluk agama lain.

Pada tindakan III dan IV dilaksanakan dengan pemberian materi IP Address Versi 4 dan Subnetting. Skenario pembelajaran yang dirancang meliputi: pertama, guru dan siswa berdoa sebelum kelas dimulai, kedua guru menerangkan konsep IP Address Versi 4 dan perhitungan subnetting, ketiga guru memperlihatkan contoh pembagian IP Address kelas A, Kelas B, Kelas C, D dan E serta memberikan contoh kasus soal perhitungan subnetting, keempat guru memberikan studi kasus soal perhitungan subnetting kepada siswa, kelima siswa mengerjakan dan menyelesaikan studi kasus perhitungan subnetting yang diberikan guru dengan cermat, guru membimbing siswa dalam menyelesaikan studi kasus soal perhitungan subnetting, keenam guru dan siswa melakukan refleksi mengenai pembelajaran yang telah berlangsung dan terakhir guru dan siswa melaksanakan Shalat Dzuhur berjamaah setelah kelas selesai dan berdoa bagi pemeluk agama lain.

Pada skenario pembelajaran di atas, tampak komponen internalisasi nilai-nilai karakter disiplin muncul pada kegiatan melakukan shalat Dhuhur berjamaah tepat waktu, disiplin belajar, disiplin masuk kelas tepat waktu, disiplin mendengarkan dengan seksama penjelasan guru, tidak pernah keluar sebelum pelajaran selesai, mengembalikan alat praktek ke tempat semula, menggunakan peralatan praktek sesuai SOP, mengikuti pelajaran dari awal sampai selesai, tidak menunda-nunda mengerjakan tugas, membuat laporan sesuai waktu yang ditetapkan guru dan datang ke sekolah tepat waktu.

Dalam kegiatan pembelajaran, guru peneliti menggunakan media pembelajaran berupa Laptop, LCD, dan buku teks serta peralatan praktik. Selain memberikan materi pembelajaran Komputer Jaringan Dasar, guru peneliti menggunakan kesempatan tersebut untuk memberikan perhatian khusus bagi siswa yang termasuk dalam kategori rendah. Siswa tersebut antara lain diminta untuk mempresentasikan hasil pekerjaannya di depan kelas atau ditanya seputar materi pelajaran yang akan, sedang, atau telah berlangsung. Guru peneliti berharap tindakan semacam ini dapat membawa kesan yang positif bagi siswa yang bersangkutan yang pada akhirnya dapat meningkatkan prestasinya pada mata pelajaran Komputer Jaringan Dasar.

Pada refleksi guru peneliti dan kolaborator melakukan refleksi bersama atas tindakan yang dilakukan selama siklus I. Untuk mendapatkan masukan dan kolaborator dalam penelitian ini, guru peneliti menerapkan validitas demokratik dan validitas dialogik. Masing-masing pihak menyampaikan pendapat dan pandangannya selama tindakan diberikan berdasarkan pengamatan dan catatan masingmasing. Selanjutnya meninjau kembali adakah perubahan yang terjadi pada komponen yang diamati, seberapa jauh tindakan telah sesuai rencana, bagaimana keberhasilannya, apa hambatan-hambatannya, serta langkah apa yang harus dilakukan pada siklus berikutnya. Hasil refleksi juga menunjukkan bahwa rata-rata nilai Komputer Jaringan Dasar yang dicapai di akhir siklus I ini adalah 65,71 dengan nilai tertinggi 85 dan nilai terendah 45 . 
Pada penelitian tindakan siklus II langkah-langkah yang dilakukan juga melalui 4 tahap, yaitu perencanaan, tindakan, observasi dan refleksi. Pada tahap perencanaan, berdasarkan refleksi pada siklus I dan hasil diskusi guru peneliti dan kolaborator, maka ditentukanlah bahwa pada siklus II akan lebih memantapkan lagi beberapa kegiatan maupun materinya. Perencanaan pada siklus II ini merupakan hasil diskusi guru peneliti dengan semua pihak yang terlibat dalam penelitian ini. Hal ini dilakukan untuk memenuhi validitas demkratik dan validitas dialogik. Agar pola karakter disiplin pada diri siswa yang mengikuti mata pelajaran Komputer Jaringan Dasar dapat lebih berkembang, direncanakan untuk menerapkan berbagai variasi kegiatan pembelajaran yang memberikan kesempatan yang lebih besar kepada siswa untuk aktif dalam mengerjakan tugas (praktek), berdiskusi, dan bekerja kelompok.

Pada tahap tindakan di bagi dalam dua tindakan, tindakan I-II dan tindakan III-IV. Tindakan I-II dengan materi topologi jaringan dan media transmisi data. Adapun skenario pembelajaran yang dirancang adalah sebagai berikut: pertama guru dan siswa berdoa sebelum kelas dimulai, kedua guru menerangkan konsep dasar topologi jaringan dan media transmisi data, ketiga guru mendemonstrasikan cara membuat topologi jaringan dan cara memilih dan menggunakan media transmisi data, keempat siswa menyiapkan komputer dan aplikasi membuat topologi jaringan dan cara memilih dan menggunakan media transmisi data sesuai dengan gambar job sheet dan tetap melakukan prosedur K3, kelima guru membimbing siswa dalam membuat topologi jaringan dan cara memilih dan menggunakan media transmisi data, keenam guru dan siswa melakukan refleksi mengenai pembelajaran yang telah berlangsung dan yang terakhir guru dan siswa melaksanakan Shalat Dzuhur berjamaah setelah kelas selesai dan berdoa bagi pemeluk agama lain.
Tindakan III-IV dengan materi protokol jaringan dan menyajikan jenis-jenis perangkat jaringan. Skenario pembelajaran yang dirancang meliputi: pertama guru dan siswa berdoa sebelum kelas dimula, kedua guru menjelaskan konsep dasar protokol jaringan, cara penggunaanya dan menjelaskan jenis-jenis perangkat jaringan, ketiga guru mendemonstrasikan tentang cara setting protokol jaringan dan mendemonstrasikan cara menggunakan jenis-jenis perangkat jaringan, keempat siswa menyiapkan alat dan bahan, menghidupkan beberapa buah komputer atau laptop, mempraktekkan cara setting protokol jaringan, mempraktekkan cara menggunakan switch, mikrotik routerboard dan lan adapter dan selalu melakukan prosedur K3, kelima guru membimbing siswa dalam mempraktekkan cara setting protokol jaringan, mempraktekkan cara menggunakan switch, mikrotik routerboard dan lan adapter, keenam guru dan siswa melakukar refleksi mengenai pembelajaran yang telah berlangsung, dan terakhir guru dan siswa melaksanakan Shalat Dzuhur berjamaah setelah kelas selesai dan berdoa bagi pemeluk agama lain.

Berikut ini merupakan salah satu gambar sikap siswa dalam melakukan praktek konfigurasi IP Address versi 4 pada sistem operasi Windows. Dalam melakukan praktek mengikuti SPO yang sudah dijelaskan pada Job Sheet.

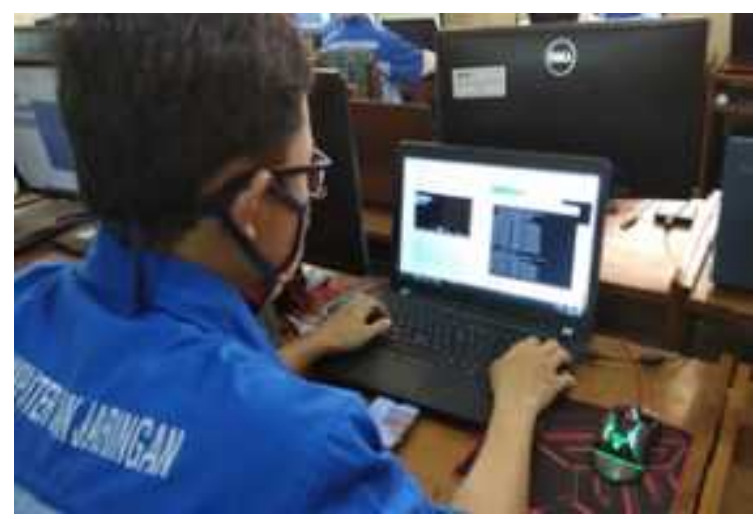

Gambar 2. Sikap siswa saat melakukan praktek Komputer Jaringan Dasar 
Pada tahap observasi dalam kegiatan pembelajaran, guru peneliti menggunakan media pembelajaran Laptop, LCD, dan modul serta peralatan praktik. Selain memberikan materi pembelajaran Komputer Jaringan Dasar, guru peneliti menggunakan kesempatan tersebut untuk memberikan perhatian khusus bagi siswa yang termasuk dalam kategori rendah. Siswa tersebut antara lain diminta untuk mempresentasikan hasil pekerjaannya di depan kelas atau ditanya seputar materi pelajaran yang akan, sedang, atau telah berlangsung. Guru peneliti berharap tindakan semacam ini dapat membawa kesan yang positif bagi siswa yang bersangkutan yang pada akhimya dapat meningkatkan prestasinya pada mata pelajaran Komputer Jaringan Dasar.

Untuk kegiatan pembelajaran Komputer Jaringan Dasar, langkah-langkah kegiatannya adalah sebagai berikut: langkah pertama adalah apersepsi, dalam tahap ini pelaksana tindakan membawa siswa masuk ke materi dengan bertanya dan memberi contoh. Maksud tahap ini untuk menyiapkan siswa agar siap dalam menerima materi yang akan diberikan.

Langkah berikutnya adalah pemberian atau penyajian materi. Dalam tahap ini peneliti sebagai pelaksana tindakan melaksanakan atau menyajikan materi Komputer Jaringan Dasar dengan pokok bahasan mendesain topologi jaringan, memilih dan menggunakan media transmisi data, menetukan protokol jaringan serta menyajikan jenis-jenis perangkat jaringan. Pembelajaran dilaksanakan dengan teknik diskusi dan penugasan. Penugasan itu sendiri dapat dilakukan secara individu maupun berkelompok. Ketika siswa diberi tugas, guru peneliti selalu berkeliling mendekati siswa guna memantau pekerjaan mereka. Pada kesempatan ini, siswa yang mengalami kesulitan dalam mengerjakan tugas dipersilakan bertanya, dan khusus bagi siswa yang prestasinya agak rendah, guru peneliti juga memberikan perhatian yang lebih dengan membantu menyelesaikan tugasnya secara tersamar dan tidak langsung. Hal ini dilakukan berulang kali setiap ada kesempatan.
Dalam setiap kesempatan, apabila siswa berhasil menyelesaikan tugasnya dengan baik, guru peneliti selalu memberikan penghargaan berupa pujian dan menunjukkan raut wajah senang. Langkah terakhir, yakni pada akhir pelajaran. Guru peneliti selalu menutup pelajaran dengan merangkum materi pelajaran yang sudah dipelajari pada hari itu. Selain itu tak lupa pula mengucapkan salam penutup yang dijawab siswa dengan sangat antusias.

Pada tahap refleksi Hasil refleksi menunjukkan terdapat beberapa perubahan pada siswa setelah kegiatan pembelajaran diisi dengan berbagai jenis kegiatan. Pertama, penugasan dan diskusi yang banyak melibatkan siswa untuk maju ke depan kelas untuk menuliskan hasil tugasnya dapat meningkatan prestasi belajar menulis siswa. Kedua, karakter disiplin siswa mengalami peningkatan. Dalam refleksi ini dapat diketahui pula perubahan pada diri siswa yang telah menunjukkan antusiasme dalam mengikuti pelajaran dengan seksama dan menunjukkan antusiasme yang tinggi. Hal tersebut membuktikan bahwa salah satu aspek penting dalam belajar adalah adanya pengetahuan pembelajar tentang tujuan melakukan sesuatu.

Pembicaraan dan diskusi antara guru peneliti dengan siswa merupakan kesempatan yang bagus untuk memberikan perhatian kepada mereka terhadap kesulitan-kesulitan atau hambatan-hambatan mereka dalam usaha meningkatkan keterampilan siswa tanpa merasa dikejar pencapaian kompetensi dasar yang telah ditetapkan. Dalam tindakan ini tujuan yang ingin dicapai tidak muluk-muluk seperti peningkatan perolehan nilai prestasi belajar yang sangat tinggi, akan tetapi walau bagaimanapun juga tindakan yang telah dilakukan tersebut telah memberikan hasil yang diinginkan.

Adapun rata-rata nilai yang dicapai di akhir siklus II ini adalah 88,11 dengan nilai tertinggi 95 dan nilai terendah 75. Data tersebut digambarkan dengan diaram batang seperti pada gambar 1. Dengan melihat hasil yang telah dicapai pada siklus ini, guru peneliti dan 
kolaborator menyimpulkan bahwa putaran tindakan-tindakan kelas yang dilakukan sudah dapat mengatasi masalah yakni peningkatan prestasi belajar siswa pada mata pelajaran Komputer Jaringan Dasar dan mengembangkan karakter disiplin para siswa.

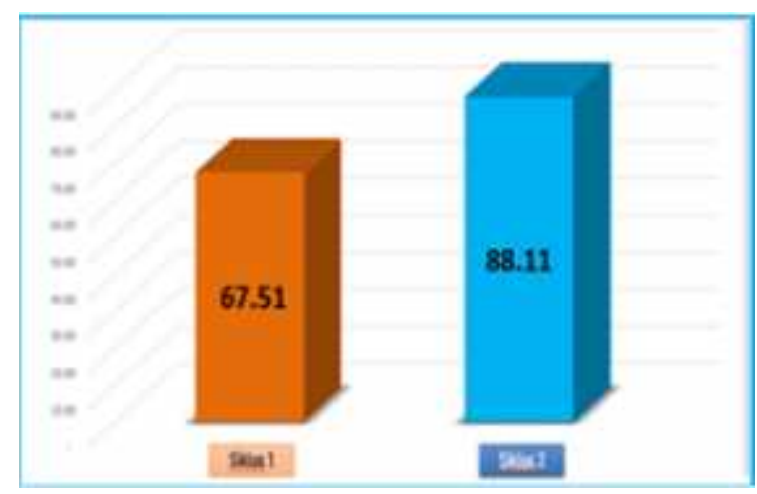

Gambar 3. Grafik peningkatan hasil belajar siswa

Selain itu, kegiatan pembelajaran pada mata pelajaran Komputer Jaringan Dasar dengan menggunakan model pembelajaran intemalisasi nilai-nilai disiplin dapat meningkatkan sikap disiplin yang seterusnya diharapkan dapat mendarah daging pada diri siswa. Hal ini dapat dilihat pada tabel 2 di bawah. Dan grafiknya dapat dilihat pada gambar 4 di bawah.

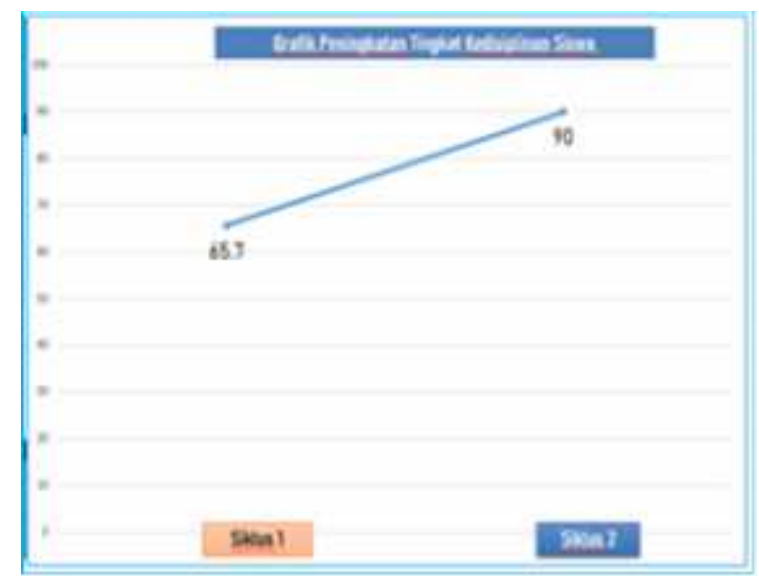

Gambar 4. Grafik peningkatan sikap/nilai disiplin siswa
Tabel 2. Hasil observasi nilai-nilai karakter displin siswa siklus I dan II

\begin{tabular}{|c|c|c|c|}
\hline No & Indikator & $\begin{array}{l}\text { Siklus } \\
\text { I }\end{array}$ & $\begin{array}{l}\text { Siklus } \\
\text { II }\end{array}$ \\
\hline 1 & Masuk kelas tepat waktu & 70 & 100 \\
\hline 2 & $\begin{array}{l}\text { Memakai seragam pakaian } \\
\text { kerja (wear pack) }\end{array}$ & 65 & 84 \\
\hline 3 & $\begin{array}{l}\text { Mendengarkan dengan } \\
\text { seksama pada saat guru } \\
\text { sedang menjelaskan }\end{array}$ & 61 & 86 \\
\hline 4 & $\begin{array}{l}\text { Berani bertanya ketika } \\
\text { belum faham materi yang } \\
\text { disampaikan guru }\end{array}$ & 65 & 89 \\
\hline 5 & $\begin{array}{l}\text { Menggunakan peralatan } \\
\text { praktek sesuai dengan } \\
\text { SOP }\end{array}$ & 62 & 94 \\
\hline 6 & $\begin{array}{l}\text { Mengembalikan peralatan } \\
\text { praktek ke tempat semula } \\
\text { dengan rapi }\end{array}$ & 70 & 90 \\
\hline 7 & $\begin{array}{l}\text { Membersihkan meja dan } \\
\text { ruangan setelah selesai } \\
\text { praktek }\end{array}$ & 71 & 87 \\
\hline 8 & $\begin{array}{lr}\text { Mengerjakan } & \text { dan } \\
\text { mengumpulkan laporan } & \text { lak } \\
\text { sesuai waktu } & \text { yang } \\
\text { ditentukan guru } & \end{array}$ & 65 & 89 \\
\hline 9 & $\begin{array}{l}\text { Mengikuti pelajaran dari } \\
\text { awal sampai akhir }\end{array}$ & 68 & 87 \\
\hline 10 & $\begin{array}{l}\text { Tidak menyontek atau } \\
\text { bertanya kepada teman } \\
\text { saat melaksanakan ujian }\end{array}$ & 60 & 94 \\
\hline & Rerata & 65,7 & 90 \\
\hline
\end{tabular}

Hasil angket nilai-nilai disiplin siswa setelah pembelajaran diketahui bahwa, sebanyak 28 siswa $(80 \%)$ memiliki tingkat kedisiplinan yang baik, 7 siswa (20\%) memiliki tingkat kedisiplinan yang sedang, dan tak seorang siswa pun yang memiliki tingkat kedisiplinan yang buruk. Adapun hasil angket respon siswa terhadap pembelajaran Komputer Jaringan Dasar diperoleh kesimpulan bahwa sebanyak 30 siswa (86\%) meniliki sikap yang baik terhadap pembelajaran Komputer Jaringan Dasar, 5 siswa (14\%) memiliki sikap yang sedang terhadap pembelajaran Komputer Jaringan Dasar, dan tak seorang siswa pun yang memiliki sikap yang buruk terhadap pembelajaran Komputer Jaringan Dasar. 


\section{SIMPULAN}

Data hasil penelitian tindakan kelas yang telah peneliti lakukan menunjukkan bahwa penggunaan model pembelajaran dengan internalisasi nilai-nilai karakter disiplin dalam pembelajaran mata pelajaran Komputer Jaringan Dasar dapat meningkatkan prestasi belajar siswa. Peningkatan tersebut terlihat pada pemahaman dan penguasaan materi siswa yang menjadi lebih baik dari sebelumnya. Hal ini dibuktikan dengan peningkatan nilai rata-rata yang diperoleh siswa berdasarkan hasil post-test Siklus I 67,51 meningkat menjadi 88,11 pada post-test siklus II. Selain itu, terjadi pula peningkatan proses pembelajaran Komputer Jaringan Dasar. Hal tersebut ditandai dengan berkurangnya kepasifan siswa dan peningkatan partisipasi siswa dalam kegiatan pembelajaran yang bermakna. Penguasaan materi dan peningkatan proses pembelajaran tersebut disertai pula dengan peningkatan karakter disiplin di kalangan siswa.

Sebagai tindak lanjut perbaikkan untuk meningkatkan karakter disiplin siswa ada beberapa saran sebagai berikut: pertama untuk mendapatkan hasil seperti yang diharapkan, guru hendaknya mampu mengembangkan polapola pembelajaran dengan memasukkan nilainilai karakter disiplin secara utuh, dan dilanjutkan dengan kesadaran diri mengenai pentingnya sifat disiplin pada diri seseorang sehingga dapat diterapkan pada kehidupan sehari-hari. Di samping itu, pembelajaran hendaknya tidak saja mengembangkan sisi kognitif namun juga mengembangkan aspek karakter siswa; kedua, kepada para siswa hendaknya selalu rneningkatkan potensi diri terutama yang berkaitan dengan jurusan yang diminatinya serta dapat melaksanakan cara belajar yang benar dan efektif misalnya dengan lebih berpartisipasi secara aktif saat proses belajar-mengajar berlangsung, membuat rencana belajar, melakukan belajar kelompok, memperbanyak mengerjakan latihan soal-soal, belajar dengan teratur, sehingga kemungkinan untuk mencapai prestasi belajar yang maksimal akan lebih besar; ketiga kepada pihak sekolah hendaknya sekolah memberikan dorongan serta menfasilitasi para guru yang akan mengadakan penelitian tindakan kelas yang tidak saja mengembangkan keilmuan siswa tapi juga karakter siswa.

\section{DAFTAR RUJUKAN}

Ahmad Rohani. 2010. Pengelolaan Pengajaran. Jakarta: Rineka Cipta.

Burns, A. 1999. Collaborative action research for English language teachers. Cambridge: University Press.

Chaplin, J. P. 2005. Kamus Lengkap Psikologi. Jakarta: Rajawali Pers.

Masykur Arif Rahman. 2011. Pentingnya Disiplin Belajar. Jakarta: Rineka Cipta.

Moenir. 2010. Masalah-Masalah dalam Belajar. Yogyakarta : Pustaka Pelajar.

Moleong, J. L. 2006. Metodologi Penelitian Kualitatif. Bandung: P.T. Remaja Rosdakarya.

Pemerintah Republik Indonesia. 2003. UndangUndang RI No. 20 tahun 2003 tentang Sistem Pendidikan Nasional.

Poerwadarminta. 2007. Kamus Umum Bahasa Indonesia. Jakarta: P.N. Balai Pustaka.

Tulus Tu'u, 2004, Peran Disiplin pada Perilaku dan Prestasi Siswa, Jakarta: P.T. Gramedia Widia Sarana Indonesia. 